\title{
男子乳癌の13例について
}

青森県立中央病院外科

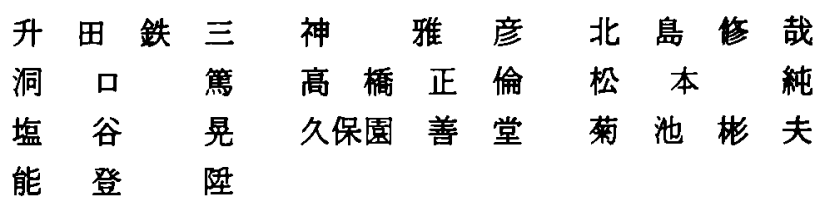

\section{A REPORT OF 13 CACES OF MALE BREAST CANCER}

Tetsuzo MASUDA, Masahiko JIN, Shuya KITAJIMA, Atsushi HORAGUCHI Masanori TAKAHASHI, Jun MATSUMOTO, Akira SHIOYA

Yoshitaka KUBOZONO, Yoshio KIKUCHI and Noboru NOTO

Department of surgery, Aomori Prefectural Central Hospital

男子乳癌は比較的まれな疾患であるが，当科では過去18年間に13例の男子乳癌を释験 し，若干の文献的考察を加えたので報告する。

発生頻度は原発乳癌全症例 541 例の $2.4 \% て ゙ ，$ 年龄分布は41歳から84藏で平均64.2歳で あった。臨床所見では13例全例に腫場が触知され，腋简リンバ節腫大 10 例，疼痛 7 例，

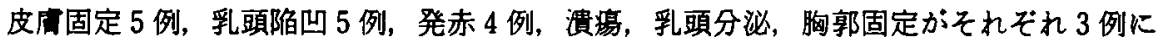
みられた，発生部位は左右とも6 例で，同時性両側例が 1 例であり，14病巣中 9 病巣は 乳頭中心性に発生していた. 大きさは径 $1 \mathrm{~cm}$ 大から $18 \times 12 \mathrm{~cm}$ におよび, 径 $2.0 \mathrm{~cm}$ 以下が 4 病笨, $2.1 \sim 5.0 \mathrm{~cm}$ が 7 病单, $5.1 \sim 10.0 \mathrm{~cm}$ が 1 病巣, 径 $10.0 \mathrm{~cm}$ 以上か 2 病巣であっ た。病悩期間が 1 年以内のbのが13例中 7 例あり，そのうちの 4 例は既に腋简りンハ節 転移があり，Stage III b，Stage IVの進行例が各 1 例であった。一方病悩期間が 6 年に 達する例が 2 例あった，病理組織学的分類では，非浸潤癌 1 例，乳頭腺管癌 5 例，䯣様 腺管癌 6 例 7 病巣, Paget 癌 1 例であった. 手術は定型的乳房切険術を 6 例 7 病巣に, 両 胸筇保存術式を 1 例に，単純乳房切断術を 2 例に，乳腺全摘術を 1 例に施行したが，单 純乳房切断術の 2 例を除き治慜手術を施行しえた。 また病態に応じて化学療法，放射線 療法, 内分泌療法, 免疫療法のいずれかを付加療法として施した。非手術例は進行例の 2 例で， 1 例に除粹術を施行した，遠隔成績をみると，原病死は 2 例のみで，いずれる 進行癌のため単純乳房切断術または非手術に終わった症例であり，少数例なから自験例 の結果をみる限り治管手術例の予後は良好と思われた。

男子乳癌は女子乳癌に比へてて予後不良といわれてきたが，今後早期発見はもちろんの こと積極的な根治的乳房切断術よび訹後の付加療法により，男子乳癌の治療成績はさ らに向上するものと思われた。

柬引用語：男子乳癌

I. はじめに

男子乳癌は比較的まれな疾患で，乳癌全症例に対す ろ頻度は本邦, 欧米とも $1 \%$ 前後との報告が多い. 男 子乳癌は, 男子と女子の乳房の解剖学的な差異もあり,
女子乳癌に比べて若干異なった病態を呈するといわれ ている，我々は，当施設で過去18年間に経悇した両側 例 1 例を含む13例の男子乳癌について検討し，若干の 文献的考察を加えたので報告する。 


\section{II. 対象症例书よU成缜}

1965年 1 月より，1983年 8 月までに，青森県立中央 病院外科で経験した原発乳癌全症例は541例であり，そ のらちの男子乳澏13例を対象とした．これは原発乳癌 全症例の $2.4 \%$ に相当しており，その年龄分布は 41 葴か ら84歳で平均 64.2 歳であった。ちななに同期間におけ る女子乳癌の年齢分布は12歳から88歳で平均 48.3 歳で あった（表 1).

臨床所見：13例全例に睡瘤が触知された。腋简リン ハ節の腫大をみたすのが10例，疼痛 7 例，皮店固定 5 例，乳頭陥凹 5 例，発赤例 4 例，溃易，乳頭分泌，胸 郭固定がそれぞれ 3 例にみられた（図 1).

発生部位：左右別発生では，左側 6 例，右側 6 例， 両側 1 例と左右差なく，またそれぞれの乳腺内腫瘤占 居部位についてみると，右側例では 7 病巣中 4 病巣， 左側例では 7 病巣中 5 病巣が乳頭中心性であった（図 2 ).

\section{表 1 乳㾔症例}

青菻県立中央病完1965.1 -1983.8

\begin{tabular}{c|c|c|c}
\hline 年歳 & 男 & 女 & 計 \\
\hline-19 & & 2 & 2 \\
$20 \sim 29$ & & 24 & 24 \\
$30 \sim 39$ & & 100 & 100 \\
$40 \sim 49$ & 1 & 187 & 188 \\
$50 \sim 59$ & 3 & 124 & 127 \\
$60 \sim 69$ & 5 & 60 & 65 \\
$70 \sim 79$ & 2 & 26 & 28 \\
$80 \sim$ & 2 & 5 & 7 \\
\hline 計 & 13 & 528 & 541 \\
& $(2.4 \%)$ & $(97.6 \%)$ & $(100 \%)$ \\
\hline
\end{tabular}

平均年龄 $\left\{\begin{array}{l}\text { 男: } 64.2 \text { 瓷 } \\ \text { 女: } 48.3 \text { 歲 }\end{array}\right.$

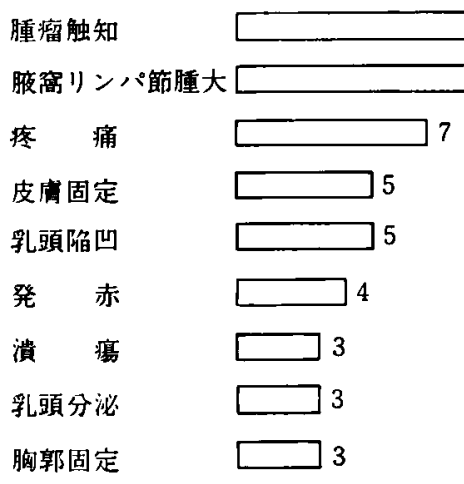

图 1 酸床所見

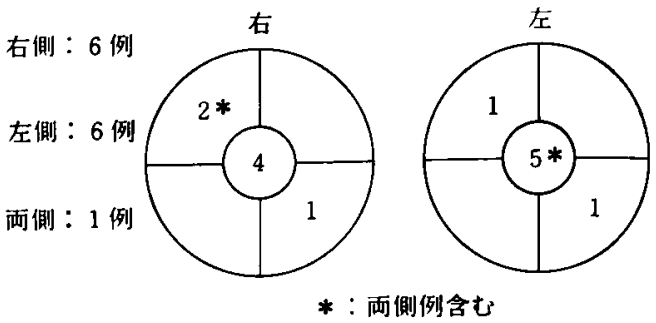

图2 左右別発生およU主占居部位

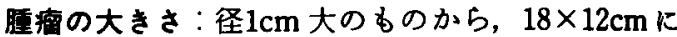
お上ぶものまでみられ，径2.0以下が 4 病笨, 2.1 5.0 $\mathrm{cm}$ か 7 病巣, $5.1 \sim 10.0 \mathrm{~cm}$ が 1 病巣, 径 $10.0 \mathrm{~cm}$ 以上 が 2 病単であった。 また周囲組織への浸潤およびリン バ節転移をみると，腫瘤径 $2.1 \mathrm{~cm}$ 以上では 10 病巣中 7 病巣に皮店固定，8病鉴にリンバ節転移が認められた (表 2).

診断：全例組織診断によったが，臨床的に悪性と診 断または悪性を強く疑ったものは 9 例のみで，残りの 4 例は術前女性乳房症あるいは良性腫煬之診断されて おり，術後組織検査で初めて悪性と診断された。

病理組織学的分類：非浸潤癌 1 例，浸泪癌12例13病 单で，浸潤癌では，乳頭腺管癌 5 例，髄様腺管癌 6 例 7 病巣, Paget 癌 1 例であった。浸润癌の場合, 乳頭腺 管癌の 3 例を除いた 9 例にリンパ節転移がみられた (表 3 ).

病悩期間と新 TNM 分類：病悩期間 1 年以内の のが13例中 7 例あり，そのうちの 4 例は既に㬸简リン バ節転移をきたしており，Stage III b, Stage IVの進 行例が各 1 例及られた。一方病悩期間が長く，6年に 達するむのが 2 例みられた（图3）.

ホルモンレセブター：両側例を含む 3 例 4 病巣につ いてホルモンレセブターを測定した。エストロゲンレ セブター (ER) は 4 病巣中 2 病巣に陽性であり,ブロ ゲステロンレセプター（PgR）は測定した 3 病巣すべ

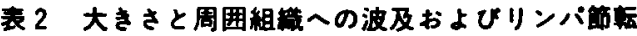 移}

\begin{tabular}{|c|c|c|c|c|c|}
\hline 大きさ $(\mathrm{cm})$ & 病啭数 & 皮周固定 & 胸郭固定 & 遠隔轱移 & $\begin{array}{l}\text { リン八管 } \\
\text { 枟 }\end{array}$ \\
\hline$\sim 2.0$ & 4 & $1 / 4$ & & & $2 / 4$ \\
\hline $2.1 \sim 5.0$ & 7 & $4 / 7$ & $1 / 7$ & & $5 / 7$ \\
\hline $5.1 \sim 10.0$ & 1 & $1 / 1$ & & & $1 / 1$ \\
\hline $10.1 \sim$ & 2 & $2 / 2$ & $2 / 2$ & $2 / 2$ & $2 / 2$ \\
\hline 計 & 14 & $8 / 14$ & $3 / 14$ & $2 / 14$ & $10 / 14$ \\
\hline
\end{tabular}




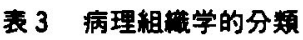

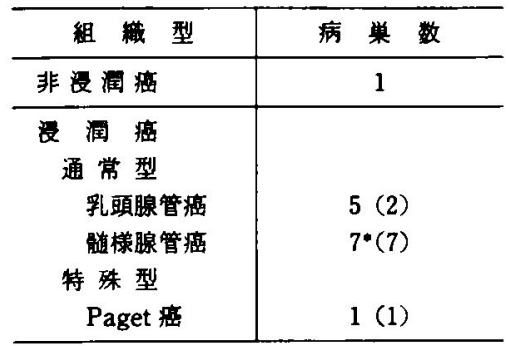

・:両側例を含む

（）：リンバ節枟移陽性

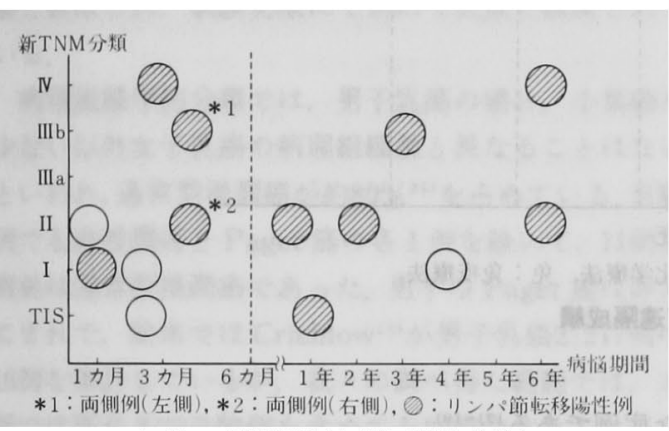

图 3 病脸期間と新 TNM 分類

てか陽性であった（表 4 ）.

手術々式：6 例 7 病巣に定型的乳房切断術を, 2 例 儿両胸筋保存術式を施行した。単純乳房切断術施行例 は 2 例あるが，1 例は助骨々膜広範浸潤例のため，他 の 1 例は手術侵襲過大などの理由によるものであっ た。また乳腺全摘例は，女性乳房症の術前猃断で手術 を受け，組織検査で非漫潤癌であったため追加手術を 施行しなかった症例である。非手術例は，左前胸壁に 巨大な潰瘍を形成し，切除不能であった症例と，畽瘤 の摘除は可能と思われたが，根治手術の承諾が得られ す除鼻術のみを施行した症例の 2 例であった（表 5).

治療およひ遠隔成缜（图 4)：治療は単純乳房切断術 に終らざるをえなかった 2 症例を除いて，乳癌取扱い

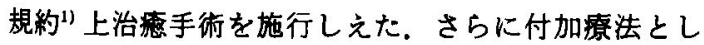
て，病態に応して化学療法 (MMC, ADM，5-Fu， Tegafur， CPA)，放射線療法，内分泌療法 (Tamoxifen, 除鼻術)，免度療法 (OK-432)が行なわ れており，非浸潤癌および高㱓者の各 1 例を除いた全 例になんらかの付加療法を施した，尚，1980年以降は 放射線療法にかわって化学療法, 内分泌療法が主体を 占めるよらになった。

遠隔成瞔をみると， 5 年以上再発を認めなかったも のが 6 例あり。そのらちの 4 例は10年以上再発を認め
表 4 ホルモンレセブター

\begin{tabular}{|c|c|c|c|}
\hline 新 TNM 分䅡 & 組織型 & ER & $\mathrm{PgR}$ \\
\hline${ }^{\prime \prime}\left\{\begin{array}{l}\text { II } \\
\text { II } \\
\text { II b }\end{array}\right.$ & 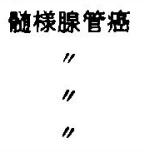 & $\begin{array}{l}196.4^{\bullet 2} \\
370.0^{\star 2}\end{array}$ & $\begin{array}{l}72.8^{\star 2} \\
57.5^{\star 2} \\
12.9^{\star 2}\end{array}$ \\
\hline
\end{tabular}

表 5 手術々式

\begin{tabular}{|c|c|c|c|c|c|c|c|}
\hline 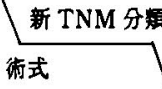 & TIS & I & II & III $\mathbf{a}$ & III $\mathrm{b}$ & IV & 計 \\
\hline $\begin{array}{l}\text { 定 型 } \\
\text { 両 胸 保 } \\
\text { 単 乳 切 } \\
\text { 乳腺全摘 }\end{array}$ & 1 & 3 & $\begin{array}{l}2^{* 1} \\
2 \\
1\end{array}$ & & $\begin{array}{l}2^{* 1} \\
1\end{array}$ & & $\begin{array}{l}7 \\
2 \\
2 \\
1\end{array}$ \\
\hline 非 手 術 & & & & & & $2^{* 2}$ & 2 \\
\hline
\end{tabular}

・1:両側例を含む

・2：1例に除重術施行

なかった，原病死は 2 例のみで(症例11，12)，いずれ も進行癌のため単純乳房切除または非手術に終わった 症例である。他病死は 3 例あり, 症例 1 は13年目心不 全, 症例 2 は 8 年 10 力月後肺炎で, 症例 6 は 8 年10力 月後老衰で死亡したが，いずれす死亡時再発の所見は 認められなかった．症例13は遠隔転移があり高龄のた め乳房切断術の承諾が得られず，除睪術と化学療法 (ADM 総 量 $40 \mathrm{mg}$ 動注, 5-Fu 総 量 $750 \mathrm{mg}$ 動 注, Tegafur 総量 $37.2 \mathrm{~g}$ 経口, Tamoxifen 総量 $1.259 \mathrm{mg}$ 経 ロ）を施行したか，10カ月の現在，腫㿇の増大傾向， 遠隔転移巣の増悪もみられず健在である。

\section{III. 考}

男子乳癌は比較的まれな疾患で，我々の調べえた籍 囲では，本邦では1980年の工藤2゙の報告以来1981年ま での91年間に318例が報告されている.第 8 回乳癌研究 会の報告3)（1970年）に上れば，本邦男子乳癌の乳癌全 症例に対する頻度は0.95\%であったといら．一方欧米 では, Sachs')205例(1940年), Treves ${ }^{51} 146$ 例(1955年), Holleb ${ }^{6)} 198$ 例（1968年), Rammantanis ${ }^{7)}$ 138例（1980 年）と比較的多数例の報告がみられるが，いずれも乳 癌全症例に対する頻度は $1 \%$ 前後であり，内外之も男 子乳癌の頻度は変りがないようである，尚，自験例は 13例で乳癌全症例の $2.4 \%$ に相当して扰り，他報告者に 比へてて比較的多い傾向にあると思われた。

本邦におりる男子乳癌患者の平均年齢は約60歳，女 


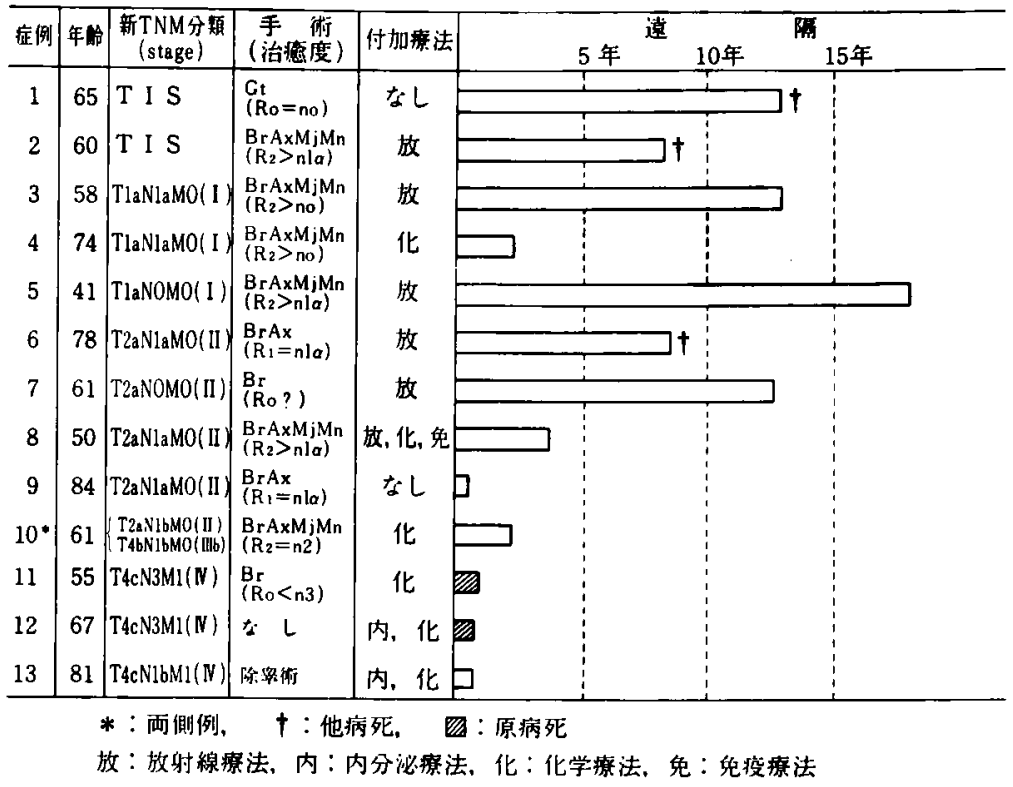

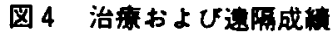

子乳癌では40～50歳台にビークがあるといら報告が多 (、38899).これは欧米です同じ㑯向であり，男子乳癌の平 均年龄は女子乳癌に比べて10歳前後高くなってい る10)11．いずれにしても男子乳癌は女子乳癌に比ぺて 高龄者に発生しており，自験例です男子64.2歳に対し， 女子乳癌は48.3歳で，男子乳癌がより高龄者に発生し ているのがわかる。

臨床所見について諸家の報告をみると，腫瘤が $80 \sim 90^{12) 13)} \%$, 腋简リンバ節腫大が50 70\% ${ }^{12114)}$, 皮庙 固定が50 60\% ${ }^{6 / 8)}$ ，疼痛が $40 \sim 50 \%{ }^{4) 51}$ ，漬瘍か

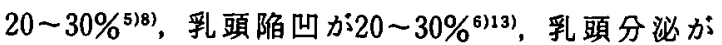
10〜15\% ${ }^{536)}$ にみられており，女子乳澏に比べてこれら 各所見の頻度が高い.9．これは男子乳腺の解剖学的な 特徵によるるので16)，乳腺が痕跡約で脂肪組織も少な く，癌が発生した場合容易に皮庙や胸筋へ浸潤し，さ らに早期に局所リンバ節へ転移することが予想され る，自呀例では全例に董瘤が触知され，腋窝リンバ節 腫大，疼痛，皮庙固定，乳頭陷凹，発赤，潰場，乳頭 分泌，胸郭固定などがみられ，症例数は少ないが他の 報告者とほぼ同じ頻度を占めていた。

左右別発生では，左側がやや優位との報告が多 (5)614), 両側例む男子乳癌の $1 \sim 2 \%$ 前後にみられる とい(5)610144，自験例では左右同数で，両側例は 1 例 のみであったが,この症例は同時性両側乳癌例であり， 我々の調べえた範囲では本邦第 4 例目に相当するまれ
な症例である(7)-191。

畽瘤占居部位は $80 \%$ 前後 ${ }^{716)}$ が乳頭中心性であり， そのため女子に比べて乳頭陌凹，乳頭分泌などの乳頭 変化がおこりやすいすのと考学られ，とくに乳頭分泌 が血性の場合は癌の可能性が高い6).

乳腺腫瘤の大きさは大半が $2.1 \sim 5.0 \mathrm{~cm}$ で, 径 $2.0 \mathrm{~cm}$ 以下は20 -30\%, 逆に径 $5.1 \mathrm{~cm}$ 以上は10２0\%にすぎ ない1620). しかし，女子乳癌に比してリンハ、節転移や猠 湯形成の頻度は高く，Heller ら ${ }^{11}$ によれば，径 $2.0 \mathrm{~cm}$ 以下の腫瘤例でも $35 \%$, 径 $2.1 \mathrm{~cm}$ 以上になると $74 \%$ に 腋苔リンバ節転移があったと述へ，Carlsson ら²0よ れば，径 $5.1 \mathrm{~cm}$ 以上の腫瘤例では全例に潰湯がみられ たといら。

自験例では, 腫瘤径 $2.1 \mathrm{~cm}$ 以上の 10 病巣 7 病巣に皮 唐同定，8病巣にリンハ節転移が認められた。

病脳期間は， 1 年以内のものは $50 \%$ 前後(313)14)に才ぎ ず，女子の $80 \%$ 前後勿に比べると長い例が多く、これが 男子乳癌の予後を悪くしている一因とも考えられてい る. 泉雄ら の病脳期間について比較し，徐々にではあるが病悩期 間が短縮しており，男子乳癌に対する関心が高まって きていることを指摘しているが，まだまだ早期発見例 は少ない，しかし，男子乳癌の場合，進行度は必ずし む病悩期間に比例せず, 前述の解剖学的特異性す関与 して比較的病悩期間が短いにもかかわらず進行してい 
ることが多く，自験例の場合でも，病悩期間が 1 年以 内の 7 例中 4 例に腋窝リンハ・節転移がみられ, Stage IIl b, Stage IVの進行例を各 1 例経験した，その一方病 悦期間か６年に達しながら根治手術をしえた症例が 1 例あり，病悦期間が 4 年以上の例が $10 \%$ 前後 ${ }^{5)}$ ，最長 20 30年 ${ }^{(3) 14)}$ とい5例も報告されており，比較的緩慢 な経過をたどる例の存在も注目に值する。

診断は腋富リンハ節触知，潰瘍形成などの随伴症状 を伴っていれば容易であるが，自験例で乳腺腫瘤のみ で来院した 4 例はいずれる女性乳房症あるいは良性腫 渲と診断され，試験切除にて初めて乳癌と診断されて いる.

病理組穖学的分類では, 男子乳癌の場合, 小葉癌が 少ない以外女子乳癌の病理組織像と異なることはない といわれ，通常型漫潤癌が約 $80 \%{ }^{21)}$ を占めている. 自験 例でも非浸潤癌と Paget 癌の各 1 例を除いて, 11例12 病宩は通常型浸潤癌であった。男子の Paget 癌は非常 にまれで，欧米では Crichlow ${ }^{22}$ が男子乳癌2,217例中 16例を集計しているか，我々の調べ得た範囲では，本 邦では現在まで自験例を含めて 5 例報告されているに すぎな(,7211)22).

最近男子乳癌とエストロゲンとの関釈が注目されて おり，男子乳癌の患者では正常男子に比べて尿中ェス トロゲン值が高いという報告や24)25), 再発時期や治療 奻果の判定にエストロゲン測定が有用であったとの報

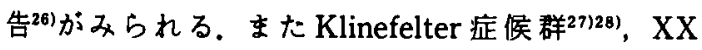
male ${ }^{29)}$ な゙の染色体異常の患者に男子乳癌の発生頻 度が高い理由として，男性ホルモン活性が低いために 相対的エストロゲン優位の状態にあることがあげられ ている。 ちなみに男子乳癌の ER 陽性率は約 $80 \%{ }^{301311}$ で,女子の $60 \%{ }^{32}$ に比べて高いといわれており，自験例 についても測定しえた 4 病巣中 2 病巣に陽性であっ た.

古くから男子乳癌と女性乳房症の関保は注目されて いるが，両者の合併例が報告されているもの

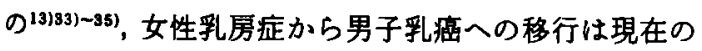
ところ証明されていない(8)111．自験例です1例に女性 乳房症の合併が認められたが，組織学的にその癌化を 証明しらる所見は得られなかった。

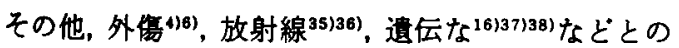
関係も述へてている報告も散見されるが，いずれもるの 烕係は不明である。

治虛は根治的乳房切断術が原則であり, 付加㞠法之 して化学療法, 放射線療法, 内分泌療法, 免度㞠法が
あるが，文献的には古い症例が多いため放射線療法を 施行されているすのが多く，化学㞠法，免疫療法に関 する報告は少ない，自験例では，1980年以降は放射線 療法にかわって化学療法, 内分泌療法を施行するょ5 になったが，その効果については今後症例を重ねて検 討したい，一方症例の $20 ３ 0 \%{ }^{4) 12)}$ を占める切除不能 例や再発例に対しては，内分泌㞠法の有奻性が指摘さ れており，抗エストロゲン㭚（Tamoxifen）の投与に

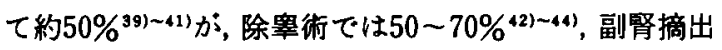

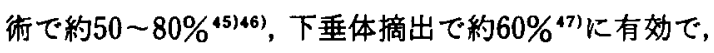
とくに ER 陽性例で有効のようである. 自験例です遠 隔転移があり高龄のため乳房切断術の承諾を得られな かった 1 例に除殬術を施行し有効性が認められた。

遠隔成樍についてみると，自験例の場合，原病死は 非手術例の 1 例と非治跑手術例の 1 例のみであり, 現 在生存中の 8 例は非切除例の 1 例を除いて再発の徵候 を認めず健在である。男子乳癌は女子乳癌に比へてて予 後が不良であるといわれてきたが，自験例の結果を見 る限り治等手術例の予後は良好と思われる. 文献的に る近年男子乳癌に対する関心が高まるにつれて 5 年生 存率も向上してきており60 70\% ${ }^{1120)}$ の報告がみられ るようになった，今後早期発見はもちろんのこと，積 極的な根治的乳房切断術および付加療法を行ならこと によって男子乳癌の治療成樍はさらに向上するすの之 思われる.

\section{IV. 桔 語}

青森県立中央病院外科で過去18年間に释験した両側 例 1 例を含む13例の男子乳癌について検討し，若干の 文献的考察を加吝て報告した。

本論文の要旨は, 第44回日本臨床外科医学会総会 (東京, 1982年）で報告した。

\section{文嗝}

1）乳癌研究会稨：乳癌取扱い規粎，金原出版，東京， 1979.

2）工藤 規：男子乳癌実験, 東京医事新誌，642： $877-878,1890$.

3）增田強三：男子乳癌 (第 8 回乳癌研究会)，蹦の踾 床, $16: 1213-1220,1970$.

4) Sachs, M.D.: Carcinoma of the male breast. Radiology, 37 : 458-467, 1941.

5) Treves, N. and Holleb, A.I.: Cancer of the male breast. Cancer, 8: 1239-1250, 1955.

6) Holleb, A.I., Freeman, H.P. and Farrow, J.H.: Cancer of the male breast. New York. J. Med., 
$68: 544-553,1968$.

7) Rammantanis, G., Besbeas, S. and Garas, J.G. : Breast cancer in the male. Word J. Surg., $4: 621$ $-624,1980$.

8）泉雄 勝,松岡正紀：男子乳腺尰瘍について, 最新 医学, $22: 2705-2717,1967$.

9)永井良治, 吉田楥: 乳癌, 日本臨床, 41 : 1311-1323, 1983.

10) Moss, N.H.: Cancer of the male breast. Ann. New York Acad. Sci., 114 : 937-950, 1964.

11) Heller, K.S., Rosen, P.P., et al. : Male breast cancer. Ann. Surg., 188: 60-65, 1978.

12) Crichlow, R.W.: Carcinoma of the male breast. Surg. Gynec. Obstet., 134 : 1011-1019, 1972.

13) Yap, H.Y., Tashima, C.K., Blumenschein, G.R., et al.: Male breast cancer. Cancer, 44: 748 -754, 1979.

14) Wainwright, J.M.: Carcinoma of the male breast. Arch. Surg., $14: 836-859,1927$.

15) Kuo, S.J., Wang, C.C., Liu, T.C., et al. : Cancer of the male breast. J. Formosan Med. Assoc., $80: 523-529,1981$.

16) Norris, H.J. and Taylor, H.B. : Carcinoma of the male breast. Cancer, $23: 1428-1435,1969$.

17）関口蕃樹：男子に発生せる乳腺癌に就て, 日外会 誌, $14: 172,1913$.

18）片岡六四郎, 林 悦郎：若年男子に発生した乳癌 の 1 例, 日外会誌, $57: 634,1956$.

19）酒井正見，暒原幸夫，平川隆孝：男子両側乳痖の 1 例, 久留米医学雑誌，22：356-358， 1959.

20) Carlsson, G., Hafström, L. and Jönsson, P.E. : Male breast cancer. Clinical Oncology, $7: 149$ $-155,1981$.

21) Visfeldt, J. and Schike, O.: Male breast cancer. Cancer, 32: 985-990, 1973.

22）安藤 博, 木内康人, 吉沢潤他：男子乳癌の 1 例 (Paget 氏病の 1 例を含む) とその性染色質, 東京 苾恵会医科大学雑誌, $84: 237-242,1969$.

23）石倉一夫, 福士 垪: 男子釈癌の 1 例, 青県病誌, $17: 149-155,1981$.

24) Dao, T.L., Morreal, C. and Nomoto, T.: Urinary estrogen excretion in men with breast cancer. N. Engl. Med., 289: 138-140, 1973.

25）野口昌邦, 木下 元, 片山宽次他：男子乳癌の 1 例 とそのホルモン依存性, 癌の臨床, 26:490-499,
1980.

26）固尾博司，森木忠興，角田悦男他：男子乳痁とその ホルモン依存性, 癌の臨床，26：490-499, 1980.

27) Jackson, A.W., Muldal, S., Ockey, C.H., et al. : Carcinoma of male breast in association with the klinefelter syndrome. Br. Med. J., $23: 223$ $-225,1965$.

28）山内晶司, 垤田明男, 宇仁田 卓他：Klinefelter 症 候群患者に発生した乳癌の1例, 臨外, 35： 1316-1318, 1980.

29) Giammarini, A., Rocchi, M., Zennaro, W., et al.: $\mathrm{XX}$ male with breast cancer. Clinical Genetics, 18 : 103-108, 1980.

30) Gupta, N., Cohen, J.L., Rosenbaum, C., et al. : Estrogen receptor in male breast cancer. Cancer, $46: 1781-1784,1979$.

31) Friedman, M.A., Hoffman, P.G., Dandolos, E. M., et al. : Hormone receptor in male breast cancer. Cancer, $47: 134-137,1980$.

32) Ruff, S.J., Bauer, J.E., Keenan, E.J., et al. : Hormone receptor in male breast cancer. J. Surg. Oncol., $18: 55-59,1981$.

33）青柳和彦, 仙石耕一, 八重樫寛治他：女性乳房症を 合併世る男子乳题の1例, 外科診療, 16 ： 693-697, 1974 .

34）渡辺昇重, 端山俊晃, 石田 清他：女性乳房を併併 存した男子乳癌の 1 例, 外科, $39: 311-313,1977$.

35）青木陽一郎, 徳岡昭治 : 男性乳癌24例の病理学的 研究, 広島医学, 33：1075-1086, 1980.

36) Lowell, D.M., Mastineau, R.G. and Luria, S.B. : Carcinoma of the male breast following radia. tion. Cancer, $22: 581-586,1968$.

37) Marger, D., Urdaneta, N. and Fischer, J.J. : Breast cancer in brothers. Cancer, $36: 458-461$, 1975.

38) Schwartz, R.M., Newell, R.B., Hauch, J.F., et al.: A study of familial male breast carcinoma and a second report. Cancer, $46: 2697$ $-2701,1980$.

39) Hortobagyi, G.N., DiStefano, A., Legha, S.S., et al.: Hormonal therapy with tamoxifen in male breast cancer. Cancer Treatment Reports, $63: 539-540,1979$.

40) Patterson, J.S., Battersby, L.A. and Bach, B.K. : Use of tamoxifen in adbanced male breast cancer. Cancer Treatment Reports, 64: 801 
$-803,1980$.

41) Tirelli, U., Toumolo, S., Talamini, R., et al.: Tamoxifen before orchiectomy in advanced male breast cancer. Cancer Treatment Reports, $66: 1882-1883,1982$.

42) Treves, N.: The treatment of cancer, especially inoperable cancer, of the male breast by ablative surgery (orchiectomy, adrenalectomy, and hypophysectomy) and hormone therapy (estrogens and corticosteroids). Cancer, $12: 820$ $-832,1959$.

43) Neifeld, J.P., Meyskens, F., Tormey, D.G., et al.: The role of orchiectomy in the manegement of advanced male breast cancer. Cancer, 37 : 992-995, 1976.
44) Kraybill, W.G., Kaufman, R. and Kinne, D. : Treatment of advanced male breast cancer. Cancer, 47 : 2185-2189, 1981.

45) Li, M.G., Janelli, D.E., Kelly, E.J., et al. : Metastatic carcinoma of the male breast treat. ed with bilateral adrenalectomy and chemotherapy. Cancer, 25 : 678-681, 1970.

46）石田常博, 泉雄 勝, 整場庄一他：男子再橆乳癌に 対する副腎剔除術の経験と文献的考察, 癌の臨床, $17: 760-765,1971$.

47) Kennedy, B.J. and Kiang, D.T.: Hypophysectomy in the treatment of advanced can. cer of the male breast. Cancer, $25: 1606-1612$, 1972. 